\title{
PENERAPAN STRATEGI PREVIEW,QUESTION, READ, REFLECT RECITE DAN REVIEW (PQ4R) UNTUK MENINGKATKAN HASIL BELAJAR
}

\author{
Oleh : \\ Ricu Sidiq
}

\begin{abstract}
Abstrak
Penelitian ini bertujuan untuk meningkatkan hasil belajar mahasiswa pada Mata Kuliah Desain Pembelajaran Sejarah melalui strategi Preview, Question, Read, Reflect, recite, Review (PQ4R) di prodi Pendidikan Sejarah kelas Non Reg yang berjumlah 30 mahasiswa. Penelitian ini akan dilaksanakan selama enam bulan, dari bulan Mei sampai bulan oktober 2016. Metode yang digunakan adalah Action Research (Penelitian Tindakan) dengan model dari Kurt Lewin. Penelitian dilakukan dalam bentuk siklus. Masing-masing siklus terdiri dari empat tahapan yakni perencanaan, tindakan, observasi dan refleksi. Peneliti bertindak sebagai pengamat, dan kolaborator adalah seorang anggota KDBK. Pada penelitian ini, akan menerapkan strategi $P Q 4 R$ dalam kegiatan perkuliahan yang digunakan pada siklus penelitian. Berdasarkan observasi awal, ada keterbatasan mahasiswa memiliki keterampilan membaca menyebabkan hasil belajar mahasiswa kurang maksimal. Semoga dengan menerapkan strategi $P Q 4 R$ dapat meningkatkan hasil belajar mahasiswa pada mata kuliah stategi belajar mengajar karena dapat mengaktifkan mahasiswa dengan menemukan atau menerapkan ide-ide mahasiswa sendiri.
\end{abstract}

Kata kunci: Action Research, PQ4R, Desain Pembelajaran Sejarah 


\section{PENDAhULUAN}

Teknik atau cara mengajar untuk meningkatkan proses pencapaian tujuan belajar dalam strategi pembelajaran sangat diperlukan. Pentingnya penguasaan terhadap teknik atau cara mengajar oleh dosen akan berpengaruh terhadap hasil belajar mahasiswa. Dengan teknik atau cara mengajar yang baik, informasi yang akan diberikan dapat bertahan lama dan bermakna. Begitupula dengan cara belajar yang baik maka hasil yang didapatkan juga akan baik. Hal ini berlaku bagi tiap mata kuliah, termasuk di dalamnya Mata Kuliah stategi belajar mengajar.

Mata Kuliah stategi belajar mengajar memiliki arti yang sangat penting sebagai mata kuliah wajib yang harus diambil mahasiswa dalam menempuh pendidikannya di jurusan ini. Melalui mata kuliah ini mahasiswa akan mampu merancang atu mendesain pembelajaran sejarah yang baik, sebagai bekalnya menjadi guru sejarah yang profesional. Ironisnya hasil belajar mahasiswa dalam mata kuliah ini masih kurang memuaskan, sehingga tdapat hambatan untuk mencapai tujuan mata kuliah tersebut.

Terdapat beberapa anggapan terkait dengan rendahnya hasil belajar mahasiswa dalam pembelajaran antara lain adanya anggapan bahwa Mata Kuliah stategi belajar mengajar mempunyai tingkat kesulitan yang tinggi, Dari informasi awal, peneliti menemukan bahwa dosen dalam kegiatan pembelajaran mengalami kesulitan karena mahasiswa sering tidak maksimal dalam melaksanakan tugas yang diberikan dosen untuk membaca sumber referensi yang sudah ditugaskan dosen.

Peneliti berdasarkan wawancara terhadap mahasiswa kelas Non Reg menemukan bahwa mahasiswa lebih menyukai belajar individual dari pada kelompok, karena belajar individu lebih memudahkan untuk mengingat materi pembelajaran. Dalam berbagai perkuliahan yang berlangsung hampir keseluruhannya menggunakan metode diskusi kelompok, sehingga mahasiswa mengalami kebosanan. Mahasiswa mengaku mengalami kesulitan dalam mempelajari sumber referensi yang diberikan oleh dosen, meskipun mahasiswa mengaku telah membaca sumber tersebut, sehingga mahasiswa membutuhkan suatu teknik atau cara yang dapat membantu kesulitannya dalam belajar. 
Berdasarkan permasalahan yang ada, peneliti mencoba meningkatkan hasil belajar mahasiswa khususnya dalam Mata Kuliah stategi belajar mengajar. Strategi Pembelajaran yang dikembangkan adalah strategi yang mengaktifkan mahasiswa, artinya Strategi Pembelajaran yang memandang bahwa mahasiswa sebagai subjek belajar yang dinamis, peran dosen hanya sebagai fasilitator. Dengan pertimbangan bahwa sebagian besar mahasiswa telah memiliki sumber belajar berupa buku teks,. Situasi ini dapat ditemukan, diantaranya dengan membangun atau mengaplikasikan strategi preview, question, read, reflect, recite, review (PQ4R) sebagai upaya untuk membantu proses belajar mengajar di kelas.

\section{PEMBAHASAN}

\section{A. Siklus Pertama}

\section{Perencanaan}

Pembelajaran pada siklus pertama dilaksanakan pada hari Senin, tanggal 5 September 2016 pukul 08.00 s.d 10.30 WIB, mengenai waku pelaksanaan ini telah didiskusikan terlebih dahulu dengan dosen mata kuliah SBM yang bertindak sebagai kolaborator. Adapun perencanaan mateti pokok "Landasan Pendidikan". yang disiapkan setelah peneliti dengan kolaborator menentukan capaian pembelajaran antara lain:

1. Peneliti menyusun Satuan Acara Pembelajaran (SAP) yang mengacu pada tindakan, yaitu pembelajaran sejarah dengan strategi $P Q 4 R$.

2. Membuat kisi-kisi soal pre-test dan pos-test

3. Menyiapkan lembar catatan observasi (pengamatan) yang digunakan peneliti untuk mencatat berbagai kejadian yang terjadi selama tindakan berlangsung.

4. Menyiapkan format observasi terhadap tingkah laku mahasiswa, format digunakan untuk mencatat sikap mahasiswa dalam mempraktekkan strategi $P Q 4 R$.

5. menyiapkan daftar hadir mahasiswa kelas Non Reg 


\section{Tindakan}

Kegiatan pembelajaran pada siklus pertama dilaksanakan pada Hari Senin tanggal 5 September 2016, dimulai pada pukul 08.00 s.d 10.30 WIB dengan tahaptahap pelaksanaan sebagai berikut:

a. Dosen mengabsensi mahasiswa, tiga orang siswa tidak hadir dengan alasan sakit

b. Dosen menyampaikan kepada mahasiswa mengenai materi yang akan dipelajari. Kemudian dosen memberi penjelasan singkat.

c. Setelah selesai memnjelaskan kemudian dosen mengadakan Pre-test Untuk mengetahui kemampuan awal mahasiswa sebelum proses pembelajaran dimulai. Pre-test berlangsung selama 15 menit.

d. Dosen mencari tahu berapa mahasiswa yang tidak membawa buku.

e. Setelah pre-test dosen menyampaikan bahwa mahasiswa akan mempraktekkan strategi PQ4R yang pernah disampaikan oleh peneliti, yaitu strategi yang terdiri atas preview, question, read, reflect, recite dan review.

f. Preview. Dosen mengingatkan mahasiswa cara membaca sekilas (preview). Tahap preview berlangsung selama 7 menit.

g. Question. Dosen meminta kepada mahasiswa untuk menyusun pertanyaan dari ide pokok yang ditemukan dengan menggunakan kata apa. Siapa, kapan, dimana, mengapa dan bagaimana. Tahap question berlangsung selama 10 menit.

h. Read. Dosen Memberikan tugas kepada mahasiswa untuk membaca secara aktif dan menjawab pertanyaan yang telah disusun sebelumnya. Tahap read dan reflect berlangsung selama 15 menit.

i. Recite. Dosen meminta mahasiswa membuat intisari dari seluruh pembahasan materi pelajaran yang sedang dipelajari. Tahap recite berlangsung dalam waktu 5 menit

j. Review. Mahasiswa meminta mahasiswa membaca kembali bahan bacaan. Berlangsung dalam waktu 2 menit.

k. Dosen dan mahasiswa bersama-sama menuyimpulkan materi yang telah dibahas. 
1. Pada akhir pembelajaran dosen mengadakan Pos-test untuk mengetahui kemampuan dan keberhasilan mahasiswa setelah mengikuti proses pembelajaran dengan strategi $P Q 4 R$. Dosen meminta mahasiswa untuk berusaha mengerjakan sendiri soal Pos-test. hasilnya menunjukkan nilai rata-rata siswa 75,83 dengan prosentase kelulusan sebesar $88,88 \%$.

\section{Observasi}

Hasil observasi ditulis berdasarkan hasil pengamatan peneliti yang telah ditulis pada lembar catatan observasi. Adapun kesimpulan awal yang diamati oleh peneliti selama kegiatan pembelajaran berlangsung sebagai berikut:

a. Kesiapan Dosen dan peneliti masih kurang hal ini terlihat dari tidak disiapkannya lembar kerja mahasiswa.

b. mahasiswa tampak kerepotan dalam menyiapkan kertas kerja mahasiswa

c. Pada saat pemberian Pre-test memakan waktu yang cukup lama untuk membagikan dan mengumpulkan lembar soal kembali.

d. Dalam pelaksanaan Strategi PQ4R mahasiswa tampak serius mengerjakan arahan dosen meskipun demikian proses pembelajaran masih diiringi dengan canda tawa.

e. Dalam pelaksanaan Strategi $P Q 4 R$ dosen tidak menjalankan tahap Review pada kegiatan mahasiswa untuk membaca intisari yang telah dibuat karena waktu yang tidak mencukupi

f. Sebagian besar mahasiswa masih belum dapat belajar secara mandiri baik saat pretest, mempraktekaan starategi PQ4R maupun dalam mengerjakan pos- test.

g. Manajemen waktu belum sesuai dengan rencana pelaksanaan yang telah dibuat.yaitu pada kegiatan pre- test.

h. Hasil rata-rata pre-test dan post-test pada siklus pertama adalah 46,94 dan 75,83 .

\section{Refleksi}

Secara garis besar kegiatan pembelajaran sejarah siklus pertama dapat dikatakan sudah cukup baik. Hal ini terlihat dari hasil rerata kelas yang sudah diatas 70,00. Namun, masih ada 4 orang mahasiswa yang masih belum mencapai ketuntasan. 
Berdasarkan perhitungan prosentase hanya 88,88\% mahasiswa yang dapat mencapai KKM., Selain itu, hasil rerata ini belum menjadi acuan bagi peneliti untuk mengambil keputusan bahwa penelitian ini sudah berhasil dengan baik karena dalam proses pembelajaran yang berlangsung masih banyak terdapat kekurangan baik dari sisi peneliti dan kolaborator maupun dari sisi mahasiswa. Kekurangan tersebut antara lain, peneliti kurang siap dalam menyediakan lembar kerja mahasiswa, mahasiswa masih ada yang tidak membawa buku paket, masih ada mahasiswa yang mencontek dan masih ada mahasiswa yang mengobrol dengan teman sebelahnya. Dari hasil kegiatan kerja mahasiswa juga didapatkan bahwa ada beberapa mahasiswa yang membuat pertanyaan yang sama dan juga terlihat dari hasil Pre-test dan Pos-test distribusi kesalahan mahasiswa dalam menjawab soal banyak yang sama dengan teman sebelahnya. Berdasarkan kekurangan-kekurangan tersebut peneliti dan kolaborator menyepakati bahwa dalam proses pembelajaran dengan strategi PQ4R pada siklus I ini, belum berjalan sesuai dengan tahapan dalam strategi PQ4R.

Hasil refleksi inilah yang akan digunakan oleh peneliti sebagai rancangan tindakan dalam siklus kedua.

\section{B. Siklus Kedua}

\section{Perencanaan}

Rencana pembelajaran untuk siklus kedua sudah ditentukan dan didiskusikan terlebih dahulu dengan kolaborator berdasarkan pada permasalahan-permasalahan hasil refleksi pada siklus pertama . Ada berbagai rancangan tindakan yang dirubah dan diperbaiki guna meningkatkan hasil belajar. mateti pokok "Media Pembelajaran". yang merupakan kelanjutan dari pokok bahasan siklus pertama. Adapun perencanaan yang disiapkan setelah peneliti dengan kolaborator menentukan capaian pembelajaran antara lain:

1. Peneliti menyususn SAP kemudian mendiskusikannya dengan kolaborator. SAP disusun dengan memperhatiksn hasil refleksi pada siklus I.

2. Menyiapkan daftar hadir mahasiswa kelas Non reg. 
3. Menyiapkan lembar catatan observasi siklus II, yang digunakan untuk mencatat kejadian-kejadian yang berlangsung selama proses pembelajaran.

4. Menyiapkan lembar kerja mahasiswa yang terformat dalam satu lembar, kemudian. Lembar ini diberikan kepada seluruh mahasiswa. Pada lembar ini tersedia format untuk mahasiswa menuliskan pertanyaan, menjawab pertanyaan dan menuliskan intisari pembahasan.

5. Menyiapkan lembar soal dan jawaban.

\section{Tindakan}

Kegiatan pembelajaran pada siklus kedua ini dilaksanakan Pada hari Senin tanggal 19 September 2016 dilaksanakan mulai pukul 08.00s.d 10.30 WIB Langkahlangkah penelitian tindakan dalam pembelajaran pada putaran kedua adalah sebagai berikut :

a. Dosen menginformasikan mengenai tujuan pembelajaran yang akan dicapai.

b. Dosen mengabsensi mahasiswa, satu orang tidak masuk karena sakit

c. Dosen menginformasikan kepada mahasiswa mengenai nilai tes pada penelitian siklus pertama dan memberikan motivasi kepada mahasiswa agar mengerjakan tugasnya.

d. Mengadakan Pre-test sebelum membahas materi pembelajaran.

e. Dosen memberikan penjelasan singkat.

f. Dosen mencari tahu apakah masih ada mahasiswa yang tidak membawa buku paket.

\section{Observasi}

Berdasarkan hasil pengamatan peneliti pada siklus kedua, tercatat bahwasanya terdapat perbedaan dibandingkan dengan siklus pertama. Hal tersebut dapat terlihat dari:

a. Ada peningkatan keaktifan mahasiswa, keseriusan mahasiswa dalam mengikuti proses pembelajaran meskipun masih ada mahasiswa yang mengobrol. 
b. mahasiswa sudah terlihat mahir dalam memeragakan strategi PQ4R hal ini terlihat dari tidak adanya mahasiswa yang bertanya mengenai instruksi dari dosen.

c. Dosen dapat menjaga motivasi mahasiswa dengan menciptakan situasi belajar yang kondusif dan menyenangkan.

d. Pengaturan waktu dalam tiap-tiap tahap sudah sesuai dengan alokasi waktu.

e. Dalam lembar kerja mahasiswa yang berisi pertanyaan, jawaban dan intisari yang ditulis mahasiswa.

f. Hasil Pos-test menunjukkan adanya peningkatan hasil belajar yaitu sebesar $78,94 \%$ jika dibandingkan dengan hasil Pre-test yang hanya mencapai prosentase kelulusan sebesar 18,42\% dan hasil Pos-test yang mencapai prosentase kelulusan 97,36\%. Rerata kelas sebesar 82,89 dan siswa 97,36\% mencapai KKM.

\section{Refleksi}

Secara garis besar kegiatan pembelajaran putaran kedua dapat dikatakan cukup baik. Hal ini terlihat dari hasil rerata mahasiswa dalam menjawab Pos-test yang mengalami peningkatan yang sangat signifikan. Mahasiswa yang dapat mencapai nilai KKM sebesar 97,36\% dengan nilai rata-rata kelas sebesar 82,89. namun penelitian tidak dihentikan hanya sampai putaran kedua, karena masih terdapat beberapa kekurangan yang harus diperbaiki, masih adanya mahasiswa yang mengobrol dengan teman sebelahnya ketika tahapan PQ4R dilaksanakan dan masih ada siswa yang tidak mengalami peningkatan hasil belajar. Peneliti dan kolaborator bersepakat bahwa kekurangan yang terjadi merupakan dampak dari belum sempurnanya pelaksanaan strategi PQ4R yang diterapkan sehingga perlu dilakuakn perbaikan-perbaikan.

Untuk lebih meningkatkan hasil belajar dalam mengukuti proses pembelajaran dengan Strategi PQ4R, maka peneliti dan kolaborator melakukan revisi rancangan pemecahan masalah siklus kedua untuk penelitian tindakan siklus ketiga. Adapun revisi rancangan tindakan tersebut sebagai berikut :

a. Peneliti dan dosen harus memperbaiki kelemahan pada putaran kedua yaitu masih adanya mahasiswa yang mengobrol saat proses pembelajaran berlangsung 
meskipun mahasiswa tersebut tetap melaksanakan tugas dari guru. Yaitu dengan memisahkan tempat duduk.

b. Pemberian Pre-test dengan cara dibacakan soalnya lebih efektif. Namun untuk putaran ketiga teknis pemberian Pre-Test akan dilakukan dengan cara penyebaran lembaran soal kepada masing-masing. Hal ini dengan pertimbangan agar tidak terjadi ketidakseimbangan antara alokasi waktu mengerjakan Pre-test dengan Postest.

c. Dosen harus memperhatikan mahasiswa dalam mempergunakan perangkat yang tidak berkaitan dengan proses pembelajaran.

d. mahasiswa yang masih memiliki distribusi jawaban yang sama dalam menjawab soal pre-test maupun pos-test pada putaran kedua ini, maka pada putaran ketiga harus dipisahkan.

e. Dalam tahap Read dan Reflect harus disediakan alokasi waktu yang cukup, dimana disesuaikan dengan materi yang dibahas.

Hasil refleksi dalam penelitian putaran kedua ini peneliti pertimbangan untuk perencanaan pada penelitian putaran ketiga.

\section{Siklus Ke III}

\section{Perencanaan}

Rencana pembelajaran pada siklus ketiga tetap mengacu kepada garis-garis besar program pengajaran dan menjalankan apa yang telah didiskusikan antara peneliti dengan kolaborator.

Adapun yang menjadi pokok pembahasan pada siklus ketiga ini adalah "Model -model Pembelajaran ". Adapun perencanaan yang disiapkan setelah peneliti dengan kolaborator menentukan capaian pembelajaran antara lain:

1. Peneliti menyususn SAP kemudian mendiskusikannya dengan kolaborator. disusun dengan memperhatiksn hasil refleksi pada siklus II.

2. Menyiapkan daftar hadir. 
3. Menyiapkan lembar catatan observasi siklus III, yang digunakan untuk mencatat kejadian-kejadian yang berlangsung selama proses pembelajaran.

4. Menyiapkan lembar kerja mahasiswa yang terformat dalam satu lembar, kemudian Menyiapkan lembar soal dan jawaban.

\section{Tindakan}

Siklus ketiga penelitian tindakan dilaksanakan pada hari Jum'at, tanggal 26 September 2016 yang di mulai pukul 08.00 s.d 10.30 WIB. Proses kegiatan pada putaran ketiga adalah sebagai berikut :

a. Dosen Mengabsensi mahasiswa, semua mahasiswa hadir dalam mengikuti proses pembelajaran pada siklus ketiga.

b. Dosen menginformasikan tentang tujuan pembelajaran yang dicapai, Kemudian memotivasi

c. Dosen mencari tahu apakah ada mahasiswa yang tidak membawa buku.

d. Sebelum masuk ke kegiatan inti, dosen memberikan Pre-test untuk mengetahui kemampuan awal mahasiswa sebelum pembelajaran dengan strategi PQ4R dimulai. Hasil Pre-test menunjukkan nilai rata-rata siswa adalah sebesar 5,59

e. Preview. Dosen meminta mahasiswa membaca sekilas (preview). mahasiswa tampak sudah terlihat mahir dalam memeragakan preview. Berlangsung selama 5 menit.

f. Questions. Dosen meminta mahasiswa membuat pertanyaan dari hasil membaca sekilas. Question berlangsung dalam 13 menit.

g. Read dan Reflect. Setelah waktu yang diberikan oleh dosen selesai untuk tahap Questions, dosen meminta mahasiswa untuk membaca secara aktif topik pembahasan yang telah disebutkan dan meminta mahasiswa untuk menanggapi bacaan sekaligus menjawab pertanyaan yang telah disusun sebelumnya. Berlangsung dalam 15 menit. 
h. Recite. Dosen meminta mahasiswa membuat intisari dari seluruh pembahasan materi pelajaran yang sedang dipelajari, Dosen meminta mahasiswa untuk membaca intisari yang telah dibuat secara vokal. Berlangsung dalam 10 menit.

i. Review. Dosen meminta mahasiswa membaca kembali bahan bacaan jika masih belum yakin dengan jawaban yang telah dibuat. Pada tahap ini tidak semua mahasiswa melakukan Review. Berlangsung dalam 2 menit.

j. Pada akhir pembelajaran dosen mengadakan Pos-test untuk mengetahui kemampuan dan keberhasilan mahasiswa setelah mengikuti proses pembelajaran dengan strategi PQ4R, hasilnya menunjukkan nilai rata-rata mahasiswa menjadi 90,00 .

\section{Observasi}

Berdasarkan hasil pengamatan peneliti dan kolaborator, bahwasanya terdapat peningkatan yang sangat signifikan antara kegiatan pembelajaran pada siklus pertama, kedua dan ketiga. Sepanjang pengamatan peneliti dan kolaborator, mengenai kegiatan pembelajaran pada siklus ketiga adalah sebagai berikut:

a. Mahasiswa tampak sudah terbiasa dengan strategi PQ4R yang diterapkan peneliti.

b. Ada beberapa mahasiswa yang telah menyelesaikan tugas yang diberikan dosen meskipun waktu yang dialokasikan untuk memgerjakan tugas dalam suatu tahapan masih ada.

c. Mahasiswa sudah tidak ada lagi menggunakan Head Set selema mengikuti pembelajaran.

d. Masih ada mahasiswa yang sering mengobrolmeskipun demikian tetap melaksanakan tugas yang diberikan dosen.

e. Hasil rerata kelas pada Pre-test dan Pos-test siklus ketiga adalah 55,90 dan 90,00

f. Prosentase siswa yang mencapai KKM sebesar 100\%, dimana terdapat 39 siswa yang hadir dalam siklus ketiga dan seluruhnya mencapai KKM. 


\section{Refleksi}

Berdasarkan hasil evaluasi dan analisis peneliti bersama kolaborator pada siklus pertama, keduadan ketiga maka dapat dipastikan bahwasanya penerapan strategi PQ4R di kelas Non reg jurusan pendidikan sejarah yang merupakan kelas yang dijadikan subjek penelitian mampu meningkatkan hasil belajar di kelas tersebut.

Berdasarkan masukan dari kolaborator yang bertindak sebagai pengajar, peneliti menyimpulkan bahwa penelitian putaran ketiga ini dapat diakhiri. Hal ini dengan beberapa pertimbangan antara lain; bahwa nilai rerata kelas telah mencapai KKM, prosentase mahasiswa yang mencapai KKM telah mencapai 100\% dan seluruh mahasiswa telah mengalami peningkatan hasil belajar yang disertai dengan proses pembelajaran yang sportif, serta khawatir mahasiswa akan bosan dengan strategi yang sama karena dalam pembelajaran di kelas sebaiknya guru tidak dominan terhadap salah satu strategi mengajar saja.

Pada siklus pertama terlihat jumlah mahasiswa yang mencapai nilai angka ketuntasam minimum yaitu ada 5,55\% untuk pre-test dan $88,88 \%$ untuk pos-tets, sedangkan yang belum memenuhi ketuntasan sebanyak 94,45\% untuk pre-test dan 11,12\% untuk Pos-test. Pada siklus kedua terjadi perubahan, bila diprosentasekan mahasiswa yang mencapai KKM sebesar 18,42\% untuk pre-test dan 97,36\% untukpostes. Namun masih terdapat seorang mahasiswa yang belum mengalami peningkatan hasil belajar dan 1 orang mahasiswa yang belum mencapai KKM. Pada siklus ketiga terjadi perubahan yang signifikan bila dibandingkan dari siklus pertama yaitu mahasiswa yang mencapai KKM sebesar 41,02\%.. Perkembangan nilai mahasiswa dapat dilihat lebih jelas pada diagram berikut:

Diagram 1

Hasil Pre test dan Pos test

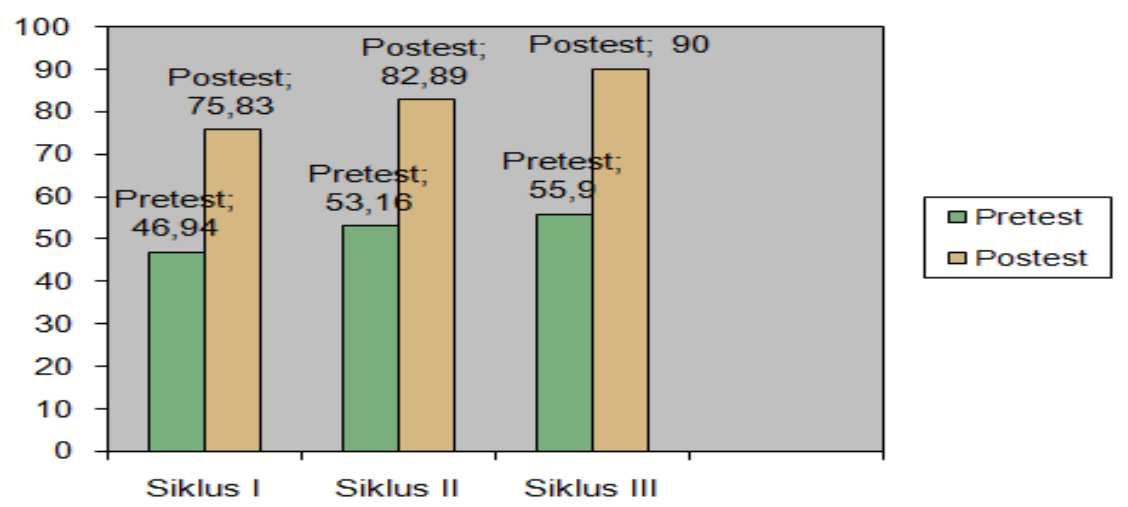




\section{Diagram .2 \\ Perbandingan Nilai Pretest}

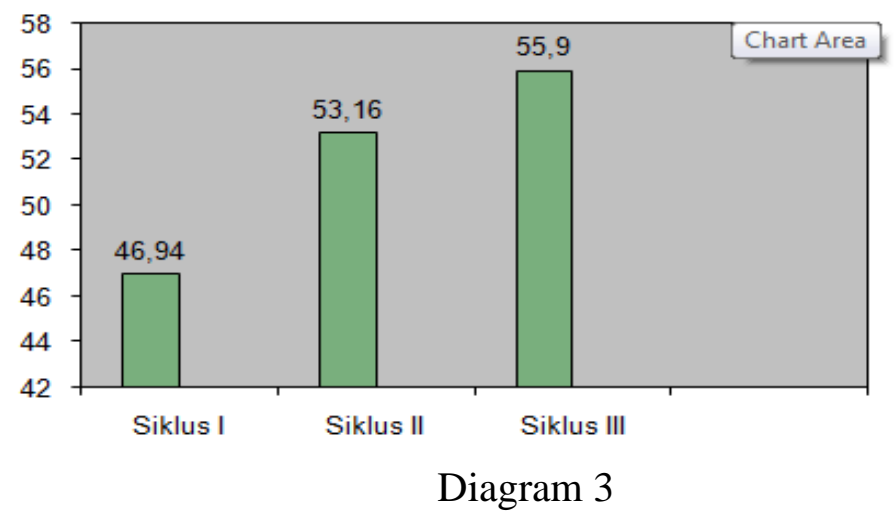

Perbandingan Nilai Postest

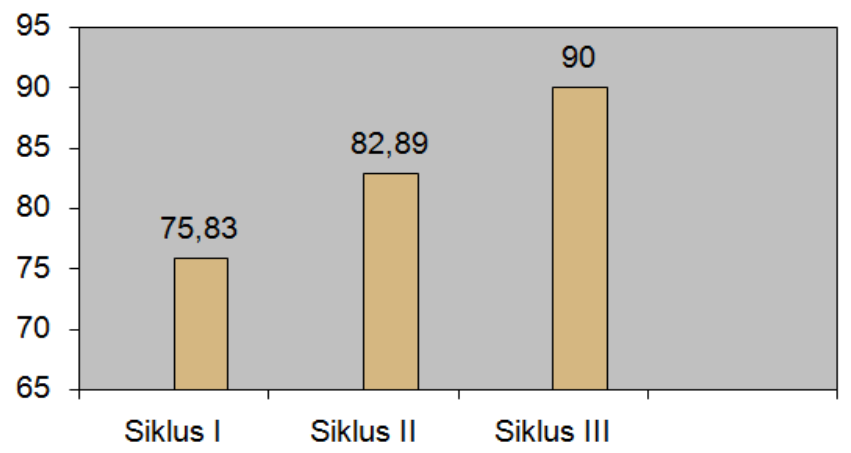

Keberhasilan pembelajaran tidak hanya dilihat dari nilai pre-test dan pos-test yang diperoleh mahasiswa akan tetapi juga memperhatikan aspek lain meliputi tingkah laku mahasiswa selama mengikuti pembelajaran. Setiap mahasiswa memiliki tingkat perkembangan yang berbeda dan cara belajar yang berbeda, hal ini disebabkan oleh faktor internal dan faktor eksternal dari masing-masing mahasiswa.

Penelitian ini berakhir sampai siklus ketiga karena hasil belajar mahasiswa telah mencapai indikator keberhasilan yang ditargekan peneliti yaitu antara lain, rerata nilai kelas telah mencapai KKM, prosentase mahasiswa yang mencapai KKM sebesar $100 \%$ dan seluruh mahasiswa mengalami peningkatan hasil belajar dalam proses pembelajaran yang baik dan sportif serta dengan pertimbangan adanya kekhawatiran 
dari peneliti dan kolaborator bahwa mahasiswa akan merasa bosan dengan strategi belajar yang sama.

\section{PENUTUP}

Berdasarkan hasil penelitian tindakan yang dilaksanakan pada bulan Mei sampai bulan oktober 2016 dapat disimpulkan bahwa: Penerapan Strategi PQ4R dapat meningkatkan Hasil Belajar. Dengan Strategi belajar yang memfokuskan pada kegiatan membaca secara aktif dengan arahan dan bimbinganm dosen, maka kreativitas mahasiswa dalam memahami materi pembelajaran meningkat. Hal ini dapat berakibat pada keaktifan mahasiswa dalam pembelajaran sehingga meningkat pula hasil belajar.

Hasil penelitian di Jurusan Pendidikan Sejarah FIS UNIMED, pembelajaran dengan Strategi PQ4R ternyata mampu meningkatkan hasil belajar mahasiswa. Hal ini dapat dilihat melalui daya serap mahasiswa setelah diadakan evaluasi belajar pada setiap akhir pertemuan dan juga proses pembelajaran siswa terlihat aktif mengikuti proses pembelajaran.

\section{DAFTAR BACAAN}

Arikunto, Suharsimi., Suhardjono, dan Supardi (2006). Penelitian Tindakan Kelas, Jakarta: Bumi Aksara.

BSNP (2007). Petunjuk Teknis Pengembangan Silabus dan Contoh/Model Silabus.Mata Pelajaran Sejarah. Jakarta: Departemen Pendidikan Nasional

Kochhar, S.K (2008). Pembelajaran Sejarah Teaching of History. Jakarta: PT Gramedia Widiasarana Indonesia.

Muslich, Mansur (2007). KTSP Pembelajaran Berbasis Kompetensi dan Konstektual, Jakarta: Bumi Aksara.

Sabri, Ahmad (2005). Strategi Belajar Mengajar Mengajar dan Microteaching, Jakarta: PT. Ciputat,

Santrock, John W (2007). Psikologi Pendidikan, terjemahan Tri Wibowo B.S, Jakarta: Prenada Media Group.

Soedarso (2001). Speed Reading, Jakarta : PT Gramedia Pustaka Utama.

Sudjana, Nana (2001). Penilaian Hasil Proses Belajar Mengajar, Bandung: Remadja Rosdakarya.

Sudjana, Nana (2006). Penelitian Tindakan Kelas, Jakarta: Bumi Aksara.

Suparno, Paul (2008). Action Research Riset Tindakan untuk Pendidik, Jakarta: Grasindo. 